\title{
Attitude of Couples and Marrigeable Singles in Establishing Joint Fashion Business
}

\author{
Adetoun Adedotun Amubode ${ }^{1}$, Hassanat Motunrayo Rauf-Lawal ${ }^{2}$ \& Boiso Maria Owodiong-Idemeko ${ }^{3}$ \\ ${ }^{1}$ Department of Home Science and Management, Federal University of Agriculture, Abeokuta, Nigeria \\ ${ }^{2}$ Department of Home Science and Management, Federal University of Agriculture, Abeokuta, Nigeria \\ ${ }^{3}$ Department of Home Economics, Adeniran Ogunsanya College of Education, Ijanikin, Lagos, Nigeria \\ Correspondence: Adetoun Adedotun Amubode, Department of Home Science and Management, Federal \\ University of Agriculture, PMB 2240, Abeokuta, Ogun State, Nigeria. E-mail: amuboto@yahoo.com
}

Received: September 21, $2015 \quad$ Accepted: October 20, 2015 Online Published: February 25, 2016

doi:10.5539/jms.v6n1p192ＵRL: http://dx.doi.org/10.5539/jms.v6n1p192

\begin{abstract}
Entrepreneurship has been observed to work among couples who have mutual understanding and trust. It has also been observed to have more advantages in terms of the synergy that can bring about achieving more, one's business been in safe hands and building marital fidelity. Nevertheless, it has also been conceived by some individuals that joint business among couples can lead to instability and arguments that arise from financial matters of the business. There are several studies in marriage and family business, effect of family on entrepreneurship, fashion marketing environment, fashion marketing strategies, fashion communication etc and none focuses on family fashion business in Nigerian socio-cultural and fashion marketing environment. Therefore, this study focuses on the attitudes of married couples and marriageable singles in establishing joint clothing and textile business. A total of 30 graduate students of Clothing and Textiles were purposefully selected for the study because they are trained to acquire vocational and entrepreneurial skills to be job creators (not job seekers), employers of labour and maintaining balance family life. Result shows that the respondents have favorable attitude to entrepreneurial skills, business management, home management, financial issues, risk management, cultural values and personality with mean scores of 3.48, 3.21, 3.13, 3.09, 3.53, 3.75 and 2.60 respectively. The overall attitudinal score is $\mathbf{3 . 2 6}$ indicating a favorable response that couples and marriageable singles can establish joint fashion business.

Therefore this study recommends that couples who intend to own joint businesses should have mutual understanding, trust and communicate more about financial matters before they own a joint business. They should discover an appropriate way of handling the business with maturity and proper organization so as to avoid conflicts.
\end{abstract}

Keywords: attitude, entrepreneurship, fashion, couples, singles, business

\section{Introduction}

Many people start up a business with friends they know and trusted and many possess complementary skills- so why not start up a business with the family (Burns, 2007). Dyer \& Gardner (2012) discovered that at least 80\% of businesses worldwide employ family members and one third of these include spouses. Family owned companies account for a substantial proportion of the value of the stock market, Leach, (1996). In the European Union, the proportion of family firm is $85 \%$ whilst in the USA, the proportion is as high as $90 \%$, Poutziouris and Chittenden, (1996). It is estimated that $70 \%$ of all U.K. businesses are family owned and employ $50 \%$ of the country's workforce, Institute for Small Business Affairs, (1999). Similarly, in the United States, Muske, (2002), informs that $15 \%$ of small businesses in 2000 were coupled owned. Coupled owned and operated businesses are a significant component of small firms.

Traditionally, family businesses have been important in many primary sectors such as farming. They also tend to thrive in areas such as hotels and restaurants where high levels of personal services are required; in retail sector-butchers, bakers; in cash generating food processing industry and in transport and distributorship (Burns, 2007). Family firms have some of the strongest brands in business today. In Britain, many family firms are household names- Barbour and Sons (makers of the British waxed jackets, founded in 1894), Morgan Motor 
Company, (makers of Morgan Sports Cars, founded in 1909), Cadbury \& Sons, (chocolate and cocoa manufacturer, founded in 1924).

Fashion is a global business; it is an exciting dynamic and creative business. Fashion is about self-expression, emotion and identity. Fashion reflects and pushes cultural and social boundaries. The mix of aesthetics, technology and business makes fashion a special and fascinating industry, Hines, 2008). If one considers human basic needs, food and clothing come near the top of the list. Food and clothing provides for our biological and physiological needs, (Hines, 2008, p. 4).

The textiles, apparel/clothing and footwear industries are consider being elements of a fashion industry, Hines, (2008). World textile and clothing markets are truly international networks of supply and demand. World trade in textiles and clothing is around US $\$ 350$ billion; textiles and clothing industries worldwide represents $7 \%$ of total world export in 2004, Hines, (2008, p. 2).

Where a spouse has limited labour market options, joining the entrepreneur spouse's business will be an attractive option (Dahl, Prang, \& Thompson, 2014). For some couples, being together all the time can help in their personal as well as business relationships, for others, it might be a recipe for divorce and business failure, (Burns, 2007). Conflict is most likely to arise in making decisions and a clear role definition and separation between work and home are important.

Couples entrepreneurship demands mutual agreement of both spouses before establishment and can have few advantages that can ensure the growth of the business in terms of the synergy that can bring about achieving more, one's business been in safe hands, helping marital fidelity and trust building but despite all this advantages there are certain drawbacks that makes this not ideal in terms of unpleasant times in business which may affect the whole family financially, conflicts in work places which if not managed can spillover to the home, boredom (when couples get back and ask how their day went because they already know, it doesn't boost the marriage fun), lack of financial trust among the couple and the risk of the business running into turbulent weather if solely relied upon as the family's major income. These problems amongst others have warranted a study on the attitude of marriageable singles and couples in establishing joint fashion business. There are several studies in marriage and family business, effect of family on entrepreneurship, fashion marketing environment, fashion marketing strategies, fashion communication etc and none focuses on family fashion business in Nigerian socio-cultural and fashion marketing environment. Therefore, this study focuses on the attitudes of married couples and marriageable singles in establishing joint clothing and textile business.

\subsection{Family Work Balance}

Balance in family business is a complex issue that involves financial values, gender roles, career paths, time management and many other factors (Patricia \& Kuhlman, 2004). Like so many of the challenges and dilemmas of marriage, balancing family and work has no easy solution and mutual understanding among the couple is required. Each spouse will have his or her own preferences and needs which might want to lead to disagreement but can be managed properly with maturity of the couple if the need for a joint business is required.

Preparation, intentionality and joint decision-making are the key to creating and maintaining the right family-work balance. Many couples experience extremely strong forces pulling them away from the priority that they would like their family to have. Family-work balance is a process, not a static achievement. It is important to make the decisions appropriately; selecting careers, jobs, raising children, allocating roles and responsibilities that will provide the opportunity for balance (Kuhlman \& Kuhlman, 2004).

\subsection{Models for Successful Family-Work Balance}

Both Full-Time Employed

According to Zimmerman (2003) middle-class and professional couples of dual-earning (partners that are full-time employed) with children perceive themselves as successful in balancing family and work by:

- $\quad$ Sharing housework (negotiating equal division of labor)

- Mutual, active involvement in child care (wives resist monopolizing and controlling, make room for equal contribution by husband)

- Joint decision-making (free expression of needs, negotiation and compromise wife perceived to have slightly more influence)

- Equal financial influence and access based on joint decision-making, planning 
- Valuing both partners' work and life goals (husband's careers somewhat more prioritized, support for separate, individual time and activities)

- $\quad$ Sharing emotional work (primacy of marital relationship, time alone together

Haddock, et al., (2001) affirm that these couples also employ adaptive strategies, including:

- Valuing family as the highest priority over professional responsibilities and advancement

- $\quad$ Deriving enjoyment and purpose from work

- Actively setting limits on work by separating family and work and negotiating with employers

- $\quad$ Focusing at work they experience limits as making them more productive at work

- $\quad$ Prioritizing family play and fun

- $\quad$ Taking pride in dual earning

- $\quad$ Living simply, giving up some material amenities in order to reduce financial pressures and work hours

- $\quad$ Proactive decision-making: "If you just define success as what you do at work, then that is all you will do. Whereas, if you define success as having a happy family and a happy marriage and [being] happy at work, then you make all those things happen."

- Recognizing the value of and protecting time for family, being present oriented

While this is not the only set of strategies for balance, it has the virtue of being one that is derived from the experience of satisfied couples.

\subsection{Modified Traditional}

In a study conducted by Marks, et al., (2001), on working-class, white couples produced a different model of balance where primary gender responsibilities are clear, with men earning while women are caretakers. For these couples, husbands' role balance is related to higher income (better providing) and spending more leisure time with their families. Wives' balance is enhanced by contributing through paid work of their own, involvement with relatives and friends, and when husbands spend time alone with children, are communicative about their own needs and are willing to change their own behavior to meet their wives' needs. Financial strain detracts from balance for both partners. To enhance balance the following coping strategies are recommended:

- Make a list of essential activities and involvements that you want to maintain.

- Set and guard limits and boundaries to protect these; say no firmly to activities that would interfere with your essentials.

- Make a list of 'don't want to do' items that are aversive, waste your time, sap your energy.

- Delegate these and other non-essential tasks and find or hire help.

- Negotiate to achieve the most advantageous arrangement possible when it's not feasible to reject or delegate an activity or task.

Clark (2002) found those individuals who communicate with work associates about family and with their family about work are more satisfied and higher functioning in both arenas.

- Make long-term plans with your partner to meet your individual and mutual balance goals.

- Engage your partner in regular short-term planning: Briefly review activities and arrangements for the coming week every Sunday evening. Briefly review activities for the next day every evening.

- Organize division of labor with your partner so that you each cover those tasks that are easiest and most enjoyable for you.

- $\quad$ Try to let go of the responsibilities your partner has accepted or you have delegated to others. Try not to control or criticize. Let go of guilt.

- Strictly prioritize tasks. Include 'slack' time in your plans and schedule. You won't be able to maintain a schedule plan that commits 110 percent of your available time, let alone accommodate 'emergencies'.

- Take care of yourself first whenever feasible. You can't do very effectively for others if you are depleted.

- Always be professional at work. Arrive at work early; leave work on a strict schedule. Block out work when at home or confine it to strictly scheduled times. Minimize weekend work. Be prepared for family 
emergencies that call you away from work. Train subordinates to cover responsibilities when you are away from work.

In contrast, Grigoriadis, (2012), informs that chaos can ensue when a successful business partnership is destroyed by marital discord. There is however, scant empirical evidence on representative entrepreneurial couples, and what little there is present a picture bearing no resemblance to the anecdotes in the popular press. Marshack's (1994) survey of 60 couples, half engaged in joint entrepreneurship and half dual-career, entrepreneurial couples exhibited much more traditional gender roles than dual-career couples. Similarly, Fitzgerald \& Muske (2002) find in a small sample from the 1997 National Family Business Survey (NFBS) that co-entrepreneurs (couples that jointly operate a business) are more likely than individual entrepreneurs to have a home-based business and less likely to harbor ambitions or expectations of business growth. Co-entrepreneurial couples are likely to trust each other better and to have more valuable carrots and sticks to force the other to invest in the business relationship.

\subsection{Family Entrepreneurial Risk Taking}

Yong Wang \& Panikkos Poutziouris (2010) discovered that family businesses act as one of the engines of the post-industrial growth process. They provide the seedbed for nurturing entrepreneurial talent across generations; a sense of loyalty to business success; long-term strategic commitment; and corporate independence (Poutziouris, 2001). Benefiting from the aligned family and business interests, family businesses are able to create an environment conducive to entrepreneurial venturing (Aldrich \& Cliff, 2003; Rogoff \& Heck, 2003; Zahra, 2005). They may promote entrepreneurial venturing by funding new business establishments or new technologies, launching new products, and opening new markets. In fact, stable and patient capital available in the family business proffers flexibility, enabling the firm to adopt more creative and innovative strategies (Sirmon \& Hitt, 2003; Teece, 1982).

Notwithstanding the concepts of risk and risk taking having attracted increasing attention in the entrepreneurship research arena (Simon, Houghton, \& Savelli, 2003; Sitkin \& Pablo, 1992), only few studies have been executed in the family business context. Some researchers argue that "family firm managers understanding of entrepreneurship is essential for creating new business, renewing its operations, and building organizational capabilities that will improve the company's responsiveness to the market" (Zahra, 2005, p. 25). They indicate that founders are often good at recognizing and exploiting opportunities in the market; able to organize /reconfigure resources available to achieve competitive advantages; and such family firms can sustain their entrepreneurial capacity through nurturing young generations and continuously engaging in entrepreneurial ventures (Aldrich \& Cliff, 2003; Zahra, Hayton, \& Salvato, 2004). On the other hand, family firms are conventionally portrayed as inward looking, conservative (Aronoff \& Ward, 1997; Sharma, Chrisman, \& Chua, 1997), and resistance to change (Hall, Melin, \& Nordqvist, 2001). The excessive concern over the business's long-term survival, under the family's umbrella, may inhibit the entrepreneurial venturing, because risky endeavor may lead to a financial loss shaking the firm's foundation (Sharma et al., 1997). The concern over ownership control may also hold back the firm from recruiting external specialists and professionals keeping the firm at a distance from reasonable risk taking.

Entrepreneurial risk taking is influenced by a diversity of factors (Covin \& Slevin, 1991). On one hand, entrepreneurial endeavour is often associated with entrepreneurs because of the unique features of these individuals (Zahra, 2005; Busenitz \& Barney, 1997). For instance, a business owner, due to his/her rich industrial and international business experiences, may invest in an unfamiliar foreign market by setting up branch and administrate the branch through appointing a family agent.

A number of variables that may influence entrepreneurial risk taking include entrepreneur-related parameters, such as owner-manager's educational background, industrial tenure and age, and family-related factors, such as family ownership stakes and the controlling generation in the family.

\subsection{Risk Taking and Entrepreneurs}

Family firms are often featured by a single dominant owner-manager with centralized authority (Schein, 1983; Poza, Alfred, \& Maheshwari, 1997; Sharma, 2004). Independent in their thinking and dedicated to the survival and prosperity of the firm, owner-managers often govern the firm on their own without paying attention to the inputs from others (Zahra, 2005).

Challenges to this authority are virtually unheard of, thus the owner-manager's influence upon business strategies and development process is often stable and long-lasting. The literature acknowledges the influential position of owner-managers (Anderson \& Reeb, 2003; Sharma, 2004) on business culture, organizational values, 
and beliefs (Schein, 1983; Collins \& Porras, 1994).

Owner-managers of family businesses are often entrepreneurs possessing special technical and managerial skills. Because of their authoritative position, they may orchestrate resources and initiatives in an entrepreneurial way to build up and maintain competitive advantage. Grable \& Lytton (1998) claim that the educational level of entrepreneurs is the most significant variable in differentiating risk-taking intensity in businesses. Entrepreneurs who have received a better education are apt to demonstrate stronger knowledge acquisition, assimilation, and transformation capability, which facilitates their generation of entrepreneurial initiatives and comprehension of business strategic operations. They are also inclined to construct formalized procedures when maneuvering business operations, which will minimize the loss that may occur in the venturing process. Equipped with this infrastructure, businesses are able to move further along the entrepreneurial venturing platform. Zahra (2005) claims that the entrepreneur's industrial tenure is associated with risk taking. A long industrial tenure may allow entrepreneurs to perceive the value of entrepreneurial venturing, driving them to promote venturing activities. A long industrial tenure will also render opportunities for entrepreneurs to reinforce their industrial networks. In family firms, organizational networks are often identical to owner-manager's personal networks. This is particularly so at the start-up stage. Nooteboom (1993, p. 289) observes that "entrepreneurs often employ a personal network of long standing relations with trusted family, colleagues, accountants, customers, local politicians, suppliers or the bank". Via network interaction, businesses are able to gather privileged information (Pollak, 1985), crucial to the success of business venturing, and share scarce resources with other firms. Uzzi (1996) confirms that well-networked firms have more opportunities for survival, in contrast to those with poor-networks.

An entrepreneur's age is recognized in the literature as an antecedent of business entrepreneurial venturing (Xiao et al., 2001; Jianakoplos \& Bernasek, 1998), and the correlation between age and risk taking tends to be negative. Overall, young entrepreneurs have intentions to realize themselves and make accomplishments through entrepreneurial venturing, such as investing in new markets, launching new products and developing new material for production/services. Any success in venturing will further provoke a young manager's confidence and passion, enabling them to consolidate their status and reputation inside and outside the business. Senior entrepreneurs, on the other hand, are apt to be more cautious because of the lessons learnt through their managerial practices. They may also be interested in taking risks, yet the frequency and level of risk taking are lower than those taken by young managers.

\subsection{Risk Taking and Families}

Recently, agency theory, a dominant theoretical paradigm deciphering the relationship between owners (i.e., principals) and managers (i.e., agents) and business performance has been increasingly adopted to shed light on managerial scenarios in family businesses (Sharma, 2004). The central tenet of agency theory is that the separation of ownership and management in firms will lead to "agency costs", a phrase coined by Jensen \& Meckling (1976) to represent the expenses of operational activities and the expenditures in establishing administrative systems to align interests of agents with those of principals (Chua, Chrisma, \& Sharma, 2003).

Agency theorists claim that a firm's risk-taking intensity is influenced by its ownership structure (Fama, 1980; Jensen \& Meckling, 1976). According to Fama \& Jensen's (1983) view, those families closely tied to the firm are inclined to bear fewer risks and choose lower levels of investments. Naldi et al., (2007) suggest two reasons to support this view: first, the owner family is apt to invest a high proportion of its wealth in the firm. By doing so, the family faces the risk of bearing a substantial financial burden if the investment fails. The loss caused by risk-taking activities is often not easy to endure and the ensuing damage can shake the business's financial foundation (Gedajlovic et al., 2004). Second, when high levels of risk are undertaken, more within the firm will be at stake than the current family's wealth. Risk-taking practices may leave the family wealth at stake and jeopardize the financial and social wellbeing of future generations (Schulze, Lubatkin, \& Dino, 2002).

Agency theorists indicate that when ownership increases, a greater alignment between the owner and the management will occur (Jensen \& Meckling, 1976; Zahra, 2005). Zahra (2005) further argues that with a high family ownership, members of the owner family will be more incentivized to engage in entrepreneurial venturing, capture opportunities to create competitive advantages, and protect the family firm from aggressive industry rivals. The success via venturing will offer more wealth and benefits to the family and consequently drive the family to commit itself to venturing.

A family firm's risk taking may also be associated with its controlling generation (Zahra, 2005). According to McConaughy \& Phillips (1999), founders of family businesses are inclined to possess special technical and managerial skills, which facilitate them in setting up and developing businesses. Firms controlled by founder 
scan create greater added value and grow rapidly. In the short-term, the profitability of the firm can be detracted due to high expenditures for capital assets and R\&D, but an appropriate investment will enable the business to construct a promising base for the next generation to exploit (Wang, Ahmed, \& Farquhar, 2007). Furthermore, the overlapping interests between the family and the business can steer the founder towards mentoring and coaching future successors. Under the founder's supervision and guidance, the descendants tend to be more professional. On the other hand, the main responsibilities of descendants are to shield the business against competition, consolidate, and enhance the assets that have been passed to them, instead of creating new businesses from scratch (Wang et al., 2007). Their operational processes are likely to be formalized and business functions more comprehensive. With better-established infrastructures, family firms in the hands of descendants, in contrast to start-ups, are legitimate to take higher level of risks and the frequency of risk taking may augment along with the evolution of the family business.

\subsection{Risk Taking and Performance}

Researchers claim that firms engage in risk taking in the hope, and under the assumption, that venturing will enable the firm to achieve competitive advantages against their rivals in relentless competition (Cornwall \& Perlman, 1990; Covin \& Slevin, 1991). In family firms, altruistic behaviour is frequently observed because of the alignment of management and ownership. Schulze et al., (2002, p. 252) define altruism as "a moral value that motivates individuals to undertake actions that benefit others without any expectation of external reward". The altruistic atmosphere, pervasive in family firms, may benefit the firm during the venturing process. For example, family firms often have unsound financial records, asset security, and equity base, making it difficult for them difficult to obtain external finance in the venturing process. Under such circumstance, family members, guided by altruistic belief, may bring in personal equity (Peterson \& Shulman, 1987) or family loans, therefore easing the firm from financial anemia (Berger \& Udell, 1998; Romano, Tanewski, \& Smyrnios, 2000). Moreover, if the firm is short of human resources in the venturing, family members who have not formally engaged in the firm may join in without claiming any financial compensation, therefore mitigating the business from the resource shortage pressure and salary payment burden. Risk-taking activities undertaken in an altruistic environment will have more opportunities to succeed.

On the other hand, researchers argue that family firms are less apt to have formalized procedures and systematic monitoring schemes because shares in family businesses are normally held by "[ . . . agents whose special relations with other decision agents allow agency problems to be controlled [. . .]" (Fama \& Jensen, 1983, p. 306). In fact, the alignment of management and ownership alleviates the demand for monitoring schemes and formalised procedures (Daily \& Dollinger, 1992; Naldi et al., 2007). Yet, firms without a formalized procedure and monitoring scheme may encounter operational obstacles in venturing. They are not fully aware of the market situation, strengths, and weaknesses of their industrial rivals, and rigour and frailty of themselves. Risk taking under such unawareness may only puzzle the business and act to destruct, rather than construct, performance. Evidence provided by Ward (1987) reveals that in 1984, 80 per cent of the 200 successful family owned manufacturing firms originally set up in 1924 no longer existed, and only 13 per cent were still owned by the same families as in 1924. The reasons for the demise of these family businesses were many, but the inability to plan strategically was a major cause (Ward, 1987).

\subsection{Succession of Family Business}

Poutziouris \& Chittenden, (1996), observe that four out of five businesses are managed by the first generation, which benefits from the entrepreneurial drive of the founder. However, less than one third of founders successfully pass ownership and management control of the family to the second generation. Only, $10 \%$ of second generation family firms are transferred to third generation and less than $5 \%$ ever reach beyond the third generation of family management. However, not all founding family business owner want to establish dynastic family firm. Burns \& Whitehouse, (1996), found that only $32 \%$ of British owner - managers wanted to pass their business on within the family, most (68\%) preferring to sell the firm to a trade buyer in order to make a capital. This contrasted strongly with Germany (57\%), Italy (62\%), and Spain (74\%) where most owner - managers wanted to keep the firm in the family, passing it down to their children. Leach, (1996), proposes that planning for succession should start early so as to allow the next generation grow into the role rather than coming as an unexpected event; involve the family and colleagues in thinking to get the commitment of everyone and establish a training process to develop the skills needed to take over the firm and over what time frame. This might involve education and training as well as job or work experience. 


\section{Method}

\subsection{The Study Area and Target Respondent}

The study was carried out among Postgraduate students in Clothing and Textiles of the Department of Home Science and Management, Federal University of Agriculture, Abeokuta, Nigeria. The respondents were purposively selected because they are trained to acquire vocational and entrepreneurial skills to be job creators, employers of labour, not job seekers and to be able maintain a stable home exhibiting mutual understanding with spouse with ability to manage marital conflicts. Majority of the students were married and others are of marriageable age, thus the target respondents are appropriate for the study.

\subsection{Population, Sample Size and Sampling Procedure}

As at the time of this study, the total population of Postgraduate students in the Department was 30; however, because of the manageable size, all the students were used for the study. Consequently there is no need of sampling the respondents.

\subsection{Instrument for Data Collection, Reliability and Data Analysis}

Data were collected using four point Likert Scale of attitudinal statements-(Strongly Agree, Agree, Strongly Disagree and Disagree) with scores of 4, 3, 2 and 1 respectively. A pilot study was conducted using Postgraduate students of a similar Department in another tertiary institution. Test re-test method of validation was used to assess the reliability of the instrument over a period of two weeks with a reliability coefficient of 0.78 . Ambiguous questions were identified and modified before the final administration of the instrument. The questionnaires were administered to the students during their Lecture free period. All the administered questionnaires were retrieved and the data was analysed using descriptive statistics such as frequency tables, percentages and mean. In order to make a decision, the Mean Likert Scale Score was categorized as shown below:

$$
\begin{aligned}
0.50 & \leq 1.49=\text { Disagree } \\
1.50 \leq 2.49 & =\text { Strongly Disagree } \\
2.50 \leq 3.49 & =\text { Agree } \\
>3.49 & =\text { Strongly Agree }
\end{aligned}
$$

\section{Result and Discussion}

Table 1. Demographic characteristics of the respondents

\begin{tabular}{lll}
\hline Variable & Frequency & Percentage (\%) \\
\hline SEX & 11 & \\
Male & 19 & 36.67 \\
Female & $\mathbf{3 0}$ & 63.33 \\
TOTAL & & $\mathbf{1 0 0 . 0 0}$ \\
AGE & 7 & \\
$21-25$ & 8 & 23.33 \\
$26-30$ & 7 & 26.67 \\
$31-35$ & 5 & 23.33 \\
36-40 & 3 & 16.67 \\
41-45 & $\mathbf{3 0}$ & 10.00 \\
TOTAL & & $\mathbf{1 0 0 . 0 0}$ \\
MARITAL STATUS & 11 & \\
Single & 19 & 36.67 \\
Married & $\mathbf{3 0}$ & 63.33 \\
TOTAL & & $\mathbf{1 0 0 . 0 0}$ \\
ETHNICITY & 24 & \\
Yoruba & 4 & 80.00 \\
Igbo & 2 & 13.33 \\
Hausa/Middle belt/others & $\mathbf{3 0}$ & 6.67 \\
TOTAL & & $\mathbf{1 0 0 . 0 0}$ \\
RELIGION & 27 & \\
Christianity & 3 & 90.00 \\
Islam & $\mathbf{3 0}$ & 10.00 \\
TOTAL & & $\mathbf{1 0 0 . 0 0}$ \\
CURRENT PROGRAMME & 26 & 86.67 \\
Masters & 4 & 13.33 \\
Ph.D. & $\mathbf{3 0}$ & $\mathbf{1 0 0 . 0 0}$ \\
TOTAL & & \\
\hline & &
\end{tabular}


Table 1 reveals that $36.67 \%$ and $63.33 \%$ of the respondents were male and female respectively. Most of the respondents were within the age of 21 to 35 years with $86.67 \%$ and $13.33 \%$ in Masters and Ph.D. Programmes respectively. Most (80\%) of the respondents were Yoruba and $90 \%$ were Christian.

Table 2. Attitudes of married/ marriageable singles in establishing joint business

\begin{tabular}{|c|c|c|c|c|c|}
\hline S/No & $\begin{array}{l}\text { Attitudinal } \\
\text { Factors }\end{array}$ & Attitudinal Statements & $\begin{array}{l}\text { Total } \\
\text { Score }\end{array}$ & Mean & Remark \\
\hline 1 & $\begin{array}{l}\text { Entrepreneurial } \\
\text { Skills }\end{array}$ & $\begin{array}{l}\text { Clothing and Textile business can be successfully done as a joint } \\
\text { business among couples. }\end{array}$ & 97 & 3.23 & Agree \\
\hline 2 & & $\begin{array}{l}\text { Market survey should be done appropriately before couples establish a } \\
\text { joint clothing and textile business. }\end{array}$ & 99 & 3.30 & Agree \\
\hline 3 & & $\begin{array}{l}\text { Couples should have proper vision before embarking on a joint clothing } \\
\text { and textile business. }\end{array}$ & 98 & 3.26 & Agree \\
\hline 4 & & $\begin{array}{l}\text { Couples should have equal/complementary knowledge and skills before } \\
\text { embarking on a joint clothing and textile business. }\end{array}$ & 107 & 3.57 & Strongly Agree \\
\hline 5 & & Each spouse should participate materially and skillfully in the business. & 105 & 3.50 & Strongly Agree \\
\hline 6 & & $\begin{array}{l}\text { It is better for couples to have different businesses. } \\
\text { TOTAL }\end{array}$ & 120 & $\begin{array}{l}4.00 \\
20.86\end{array}$ & $\begin{array}{l}\text { Strongly Agree } \\
\text { 3.48 (Agree) }\end{array}$ \\
\hline 7 & $\begin{array}{l}\text { Business } \\
\text { Management }\end{array}$ & $\begin{array}{l}\text { The husband should be the sole director while the wife should only } \\
\text { support. }\end{array}$ & 67 & 2.23 & Strongly Disagree \\
\hline 8 & & $\begin{array}{l}\text { Both spouses should have equal and total rights to the business } \\
\text { management. }\end{array}$ & 102 & 3.40 & Agree \\
\hline 9 & & Couples managerial decisions should be legally documented & 120 & 4.00 & Strongly Agree \\
\hline 10 & & Couples can employ extended family members to run the business. & 72 & 2.40 & Strongly Disagree \\
\hline 11 & & $\begin{array}{l}\text { Couples children can continue the business. } \\
\text { TOTAL }\end{array}$ & 120 & $\begin{array}{l}4.00 \\
\mathbf{1 6 . 0 3}\end{array}$ & $\begin{array}{l}\text { Strongly Agree } \\
\text { 3.21 (Agree) }\end{array}$ \\
\hline 12 & $\begin{array}{l}\text { Home } \\
\text { Management }\end{array}$ & $\begin{array}{l}\text { Mutual understanding in balancing the home and work/business is vital } \\
\text { between couples. }\end{array}$ & 108 & 3.60 & Strongly Agree \\
\hline 13 & & Having joint business with my spouse will cause marital conflicts. & 113 & 3.77 & Strongly Agree \\
\hline 14 & & Mutual trust is a vital requirement for couples to establish joint business. & 118 & 3.93 & Strongly Agree \\
\hline 15 & & $\begin{array}{l}\text { Housework should be shared between the couples. } \\
\text { TOTAL }\end{array}$ & 37 & $\begin{array}{l}1.23 \\
\mathbf{1 2 . 5 3}\end{array}$ & $\begin{array}{l}\text { Disagree } \\
\text { 3.13 (Agree) }\end{array}$ \\
\hline 16 & Financial Issues & Couples should have equal access to finance/profit. & 116 & 3.87 & Strongly Agree \\
\hline 17 & & Couple should receive the same salary. & 71 & 2.36 & Strongly Disagree \\
\hline 18 & & Financial decision should be made jointly. & 120 & 4.00 & Strongly Agree \\
\hline 19 & & Couple should have joint salary account. & 73 & 2.43 & Strongly Disagree \\
\hline 20 & & The husband should earn more than the wife. & 43 & 1.43 & Disagree \\
\hline 21 & & $\begin{array}{l}\text { The salary for each spouse should depend on the roles of individual in } \\
\text { the business. }\end{array}$ & 114 & 3.80 & Strongly Agree \\
\hline \multirow[t]{2}{*}{22} & & $\begin{array}{l}\text { Couple should contribute the same amount for the business start-up } \\
\text { capital. }\end{array}$ & 112 & 3.73 & Strongly Agree \\
\hline & & TOTAL & & 21.62 & 3.09 (Agree) \\
\hline 23 & $\begin{array}{l}\text { Risk } \\
\text { Management }\end{array}$ & $\begin{array}{l}\text { Poor knowledge of clothing and textile/entrepreneurship skill from either } \\
\text { spouse will pose a risk. }\end{array}$ & 101 & 3.37 & Agree \\
\hline 24 & & $\begin{array}{l}\text { In case the business faces challenges, my spouse will leave me to handle } \\
\text { it alone. }\end{array}$ & 97 & 3.23 & Agree \\
\hline 25 & & $\begin{array}{l}\text { Lack of interest in the business from either of the spouse can affect the } \\
\text { success of the business. }\end{array}$ & 97 & 3.23 & Agree \\
\hline 26 & & Insufficient profit my result to business closure. & 114 & 3.80 & Strongly Agree \\
\hline 27 & & $\begin{array}{l}\text { The family will face financial stress especially when the business newly } \\
\text { take-off. }\end{array}$ & 118 & 3.93 & Strongly Agree \\
\hline 28 & & $\begin{array}{l}\text { Death of a spouse may lead to closure of the business. } \\
\text { TOTAL }\end{array}$ & 109 & $\begin{array}{l}3.63 \\
21.19\end{array}$ & $\begin{array}{l}\text { Strongly Agree } \\
\text { 3.53 (Strongly Agree) }\end{array}$ \\
\hline 29 & Culture & Yoruba culture does not encourage joint business. & 118 & 3.93 & Strongly Agree \\
\hline 30 & & Extended family members will intrude into the business. & 115 & 3.83 & Strongly Agree \\
\hline 31 & & Wife/wives especially would be at disadvantage in joint business. & 120 & 4.00 & Strongly Agree \\
\hline \multirow[t]{2}{*}{32} & & $\begin{array}{l}\text { Pressure to recruiting unskilled family members may result to marital } \\
\text { conflict. }\end{array}$ & 97 & 3.23 & Agree \\
\hline & & TOTAL & & 14.99 & 3.75 (Strongly Agree) \\
\hline
\end{tabular}




\begin{tabular}{|c|c|c|c|c|c|}
\hline 33 & Personality & $\begin{array}{l}\text { I can confidently have a joint clothing and textile business with my } \\
\text { spouse. }\end{array}$ & 84 & 2.80 & Agree \\
\hline 34 & & My spouse can solely take managerial position of the business. & 67 & 2.23 & Strongly Disagree \\
\hline 35 & & My spouse will value my contribution if we have joint business. & 91 & 3.03 & Agree \\
\hline 36 & & My spouse will appreciate me if we have joint business. & 89 & 2.96 & Agree \\
\hline 37 & & I put myself at a disadvantage if I have joint business with my spouse. & 113 & 3.77 & Strongly Agree \\
\hline 38 & & Balancing family business and work will be a challenge to me. & 92 & 3.06 & Agree \\
\hline 39 & & $\begin{array}{l}\text { Lack of financial trust will hinder me from having joint business with } \\
\text { my spouse }\end{array}$ & 116 & 3.87 & Strongly Agree \\
\hline 40 & & I will take pride in joint business with my spouse. & 43 & 1.43 & Disagree \\
\hline 41 & & $\begin{array}{l}\text { Establishing joint clothing and textiles business with my spouse may } \\
\text { lead to divorce. }\end{array}$ & 41 & 1.37 & Disagree \\
\hline \multirow[t]{2}{*}{42} & & $\begin{array}{l}\text { Having joint business with my spouse will make our relationship } \\
\text { stronger. }\end{array}$ & 43 & 1.43 & Disagree \\
\hline & & TOTAL & & 25.95 & 2.60 (Agree) \\
\hline
\end{tabular}

Attitude of couples and marrigable singles in establishing joint Clothing and Textile business is:

$$
\frac{\text { Total Mean Likert Score }}{\text { Number of Statement }}=\frac{22.79}{7}=3.26
$$

The table reveals the Mean Score of the attitudes of couples and marriageable singles in establishing a joint fashion business. For instance the entrepreneurial skills of statements number 1, 3, 4 and 6 with mean scores of 3.23, 3.26, 3.57 and 4.00 respectively show that clothing and textile business can be successfully done as a joint business among couples; couples should have proper vision before embarking on a joint clothing and textile business; couples should have equal/complementary knowledge and skills before embarking on a joint clothing and textile business and It is better for couples to have different businesses. This is in line with Burns (2007) that many people startup business with those they know and trusted.

The business management attitudinal statements 8 , 9and 11 with mean score of, 3.40, 4.00, and 4.00 respectively indicate that both spouses should have equal and total rights to the business management; couples managerial decisions should be legally documented; and couples children can continue the business. All the respondents $(100 \%)$ would want to pass on the business to their children. This is similar to the findings of Burns and Whitehouse, (1996) that in Germany (57\%), Italy (62\%), and Spain (74\%) owner - managers wanted to keep the firm in the family, passing it down to their children. On the other hand, statements 7 and 10 with mean score of 2.23 and 2.40 respectively have unfavorable response indicating that husband should not be the sole director while the wife only support; and that couples should not employ extended family members to run the business.

Statements 12,13 and 14 with mean score of $\mathbf{3 . 6 0}, \mathbf{3 . 7 7}$ and $\mathbf{3 . 9 3}$ respectively reveals that mutual understanding in balancing the home and work/business is vital between couples; having joint business with my spouse will cause marital conflicts and mutual trust is a vital requirement for couples to establish joint business. This confirms Patricia and Kuhlman (2004), that mutual understanding among couples is required in balancing family and work.

The findings of statements 18,20 and 21 on financial issues with mean scores of $\mathbf{4 . 0 0}, \mathbf{1 . 4 3}$ and $\mathbf{3 . 6 3}$ respectively reveals that financial decision should be made jointly, the husband should not earn more than the wife, and that the salary for each spouse should depend on the roles of individual in the business. It can however be deduced that the respondents value financial transparency. However, the cultural norms may inhibit joint business among couples as revealed by statements $29,30,31$ and 32 with mean scores of $\mathbf{3 . 9 3}, \mathbf{3 . 8 3}, \mathbf{4 . 0 0}$ and $\mathbf{3 . 2 3}$ respectively indicating that Yoruba culture does not encourage joint business, extended family members will intrude into the business, wives especially would be at disadvantage in joint business and pressure to recruiting unskilled family members may result to marital conflict.

There are many other statements that support the view that the couples and marriageable singles can establish joint clothing and textile business, however further research should be carried out among married couples with either one or both spouses in fashion/ clothing business.

\section{Conclusion}

Joint business among couples has been confirmed to have more advantages than disadvantages. Nevertheless, this study confirms that couples that are involved in joint business should have appropriate ways of handling the business so as to avoid marital instability. The major issues that have been observed to be obstacles to successful 
joint business among the couples are lack of trust, mishandling of finances, conflicts in the office, undefined business roles and bringing home issues to the business front. It has been observed that amongst all these disadvantages, financial issues tend to cause conflicts more amongst couples. Mutual agreement and understanding should be present in the marriage before the thought of joint business should be conceived. It has also been observed that when roles are not properly defined, the business might not have a proper direction. Proper organization should be considered a priority in the business to avoid conflicts among the couples. For couples who have fragile marriages, it is advisable for them to have different businesses or understand themselves better before starting a joint business.

\section{References}

Aldrich, H. E., \& Cliff, J. E. (2003). The Pervasive Effects of Family on Entrepreneurship: Toward a Family Embeddedness Perspective. Journal of Business Venturing, 18(5), 573-596. http://dx.doi.org/10.1016/S0883-9026(03)00011-9

Anderson, R., \& Reeb, D. (2003). Founding Family Ownership and Firm Performance: Evidence from the S \& P 500. Journal of Finance, 58, 1301-1328. http://dx.doi.org/10.1111/1540-6261.00567

Arizon, M. J., Andre, E. F., \& Salinas, E. M. (2013). Purchase Decision Making in Couple: Conflict Solving Tactics. International Journal of Business and Social Science, 4(6), 28-43. Retrieved from http://ijbssnet.com/journals/Vol_4_No_6_June_2013/5.pdf

Aronoff, C. E., \& Ward, J. L. (1997). Preparing Your Family Business for Strategic Change. Family Business Leadership Series, 9. Marietta, GA: Business Owner Resources. Retrieved from http://www.gbv.de/dms/zbw/635155427.pdf

Barney, J. B. (1991). Firm Resources and Sustain Competitive Advantage. Journal of Management, 17(1), 99-120. http://dx.doi.org/10.1177/014920639101700108

Berger, A. N., \& Udell, G. F. (1998). The Economics of Small Business Finance: The Roles of Private Equity and Debt Markets in the Financial Growth Cycle. Journal of Banking \& Finance, 22, 613-673. http://dx.doi.org/10.1016/S0378-4266(98)00038-7

Brockhaus, R. H. (1994). Entrepreneurship and Family Business Research: Comparisons, Critique, and Lessons. Entrepreneurship Theory \& Practice, 19(1), 25-38.

Brush, C. G., \& VanderWerf, P. A. (1992). A Comparison of Methods and Sources for Obtaining Estimates of New Venture Performance. Journal of Business Venturing, 7(2), 157-170. http://dx.doi.org/10.1016/0883-9026(92)90010-O

Burns, P. (2007). Entrepreneurship and Small Business. New York: Palgrave Macmillan.

Burns, P., \& Whitehouse, O. (1996). Family Ties, 31 Europeans Enterprise Centre, Special Report No.10.

Busenitz, L. W., \& Barney, J. B. (1997). Differences between Entrepreneurs and Managers in Large Organisations: Biases and Heuristics in Strategic Decision-Making. Journal of Business Venturing, 12, 9-30. http://dx.doi.org/10.1016/S0883-9026(96)00003-1

Butt, S., Grable, J. E, Nelson, G. B. S., \& White, M. (2008). Financial Counseling and Planning: The Influence of Perceived Spending Behaviours on Relationship Satisfaction. Association for Financial Counseling and Planning Education, 19(1).

Chua, J. H., Chrisman, J. J., \& Sharma, P. (2003). Succession and Non-Succession Concerns of Family Firms and Agency Relationship with Non-Family Managers. Family Business Review, 16(2), 89-107. http://dx.doi.org/10.1111/j.1741-6248.2003.00089.x

Clark. (2002). Balancing Family and Work. Retrieved from http://www.innovativefinancial.com/newsletters/January2011/lgbalancingfamily.html

Collins, Js. C., \& Porras, J. I. (1994). Built to Last: Successful Habits of Visionary Companies. New York: Harper Collins.

Cornwall, J. R., \& Perlman, B. (1990). Organisational Entrepreneurship. Homewood, IL: Richard D. Irwin.

Covin, J. G., \& Slevin, D. P. (1991). A Conceptual Model of Entrepreneurship as Firm Behaviour. Entrepreneurship Theory \& Practice, 16(1), 7-25. .Retrieved from http://kisi.deu.edu.tr//ethem.duygulu/covin\%20ve\%20slevin.pdf

Covin, J. G., \& Slevin, D. P. (1998). Adherence to Plans, Risk taking, and Environment as Predictors of Firm 
Growth. The Journal of High Technology Management Research, 9(2), 207-237. http://dx.doi.org/10.1016/S1047-8310(98)90005-0

Dahl, M. S., Praag, M. V., \& Thompson, P. (2014). Entrepreneurial Couples. IZA Discussion Paper No.8186. http://dx.doi.org/10.2139/ssrn.2434520

Daily, C. M., \& Dollinger, M. J. (1992). An Empirical Examination of Ownership Structure in Family and Professionally Managed Firms. Family Business Review, 5(2), 117-136. http://dx.doi.org/10.1111/j.1741-6248.1992.00117.x

Deakins, D., \& Freel, M. (2003). Entrepreneurship and Small Firms. London: McGraw-Hill.

Dyer, W. G., Dyer, W. J., \& Gardner, R. G. (2012). Should My Spouse be My Partner? Preliminary Evidence from the Panel Study of Income Dynamics. Family Business Review, 26(1), 68-80. http://dx.doi.org/10.1177/0894486512449354

Easey, M. (2009). Fashion Marketing. United Kingdom: Willey-Blackwell.

Ewherido, F, (2014). Marriage and Family: Spouses in Jointly Owned Businesses, Vanguard.

Fama, E. (1980). Agency Problems and the Theory of the Firm. Journal of Political Economy, 88(2), 288-307. http://dx.doi.org/10.1086/260866

Fama, E., \& Jensen, M. C. (1983). Separation of Ownership and Control. Journal of Law and Economy, 26(2), 301-325. http://dx.doi.org/10.1086/467037

Finkelstein, S., \& Hambrick, D. C. (1996). Strategic Leadership: Top Executives and Their Effects on Organizations, West, Minneapolis, MN.

Fitzgerald. M. A., \& Muske, G. (2002). Copreneurs: An Exploration and Comparison of other Family Businesses. Family Business Review, 19(1), 1-16. http://dx.doi.org/10.1111/j.1741-6248.2002.00001.x

Gedajlovic, E., Lubatkin, M., \& Schulze, W. S. (2004). Crossing the Threshold from Founder Management to Professional Management: a Governance Perspective. Journal of Management Studies, 41(5), 899-912. http://dx.doi.org/10.1111/j.1467-6486.2004.00459.x

Grable, J. E., \& Lytton, R. H. (1998). Investor Risk Tolerance: Testing the Efficacy of Demographics as Differentiating and Classifying Factors. Financial Counseling and Planning, 9(1), 61-73. Retrieved from http://citeseerx.ist.psu.edu/viewdoc/download?doi=10.1.1.334.5627\&rep=rep1\&type=pdf

Grigoriadis, V. (2012). Tory Burch's Ex Factor. Vanity Fair, December.

Haddock, S. A., Zimmerman, T. S., Ziemba, S. J., \& Current, L. R. (2001). Ten Adaptive Strategies for Family and Work Balance: Advice from Successful Families. Journal of Marital and Family Therapy, 27(4), 445-458. http://dx.doi.org/10.1111/j.1752-0606.2001.tb00339.x

Hall, A., Melin, L., \& Nordqvist, M. (2001). Entrepreneurship as Radical Change in Family Business: Exploring the Role of Cultural Patterns. Family Business Review, 14(3), 193-208. http://dx.doi.org/10.1111/j.1741-6248.2001.00193.x

Hines, T. (2008). Globalization: Global Markets and Global Supplies in Hines and Bruce, Fashion Marketing: Contemporary Issues (pp. 1-26). Oxford: Butterwoth-Heinemann.

Hines, T., \& Bruce, M. (2008). Butterworth-Heinemann, United Kingdom.

Institute for Small Business Affairs. (1996). All in the Family, Policy and Research Issues, No. 1. August.

Jensen, M. C. (1998). Self-interest, Altruism, Incentives, and Agency-Foundations of Organizational Strategy. Cambridge, MA: Harvard University Press.

Jensen, M. C., \& Meckling, W. (1976). Theory of the Firm: Managerial Behaviour, Agency Costs and Ownership $\begin{array}{lllll}\text { Structure. Journal of Financial 305-360. } & \text { Economics, }\end{array}$ http://dx.doi.org/10.1016/0304-405X(76)90026-X

Jianak, O, A., \& Bernasek, A. (1998). Are Women More Risk Averse? Economic Inquiry, 36(4), 620-631.

Kuhlman, P. S., \& Kuhlman, G. A., (2004). Marriage Success Training: Balancing Family and Work. http://dx.doi.org/10.1111/j.1465-7295.1998.tb01740.x

Leach, P. (1996). The BDO, Stoy Hayward Guide to the Family Business. London: Kogan.

Lumpkin, G. T., \& Dess, G. G. (1996). Clarifying the Entrepreneurial Orientation Construct and Linking it to 
Performance. Academy of Management Review, 21(1), 135-172. Retrieved from http://instruct.uwo.ca/business/bus020-mwf/PHD-4.pdf

Lussier R. N., \& Sonfield, M. C. (2010). A Six-Country Study of First-, Second-, and Third-Generation Family Businesses. International Journal of Entrepreneurial Behaviour \& Research, 16(5), 414-436. http://dx.doi.org/10.1108/13552551011071869

Marks, S. R., Huston, T. L., Johnson, E. M., \& MacDermid, S. M. (2001). Role Balance among White married $\begin{array}{lllll}\text { Couples. Journal of Marriage and Family, 63, 1083-1098. } & \text {. }\end{array}$ http://dx.doi.org/10.1111/j.1741-3737.2001.01083.x

Marshack, Kathy, J. (1994). Copreneurs and Dual Career Couples: Are they Different? Entrepreneurship: Theory and Practice, 19(1), 49-69. Retrieved from http://www.highbeam.com/doc/1G1-17042908.html

McConaughy, D. L., \& Phillips, G. M. (1999). Founders versus Descendants: The Profitability, Efficiency, Growth Characteristics and Financing in Large, Public, Founding-Family-Controlled Firms. Family Business Review, 12(2), 123-131. http://dx.doi.org/10.1111/j.1741-6248.1999.00123.x

McPherson, M. (2010). Business Practices within South Asian Family and Non- Family Firms: A Comparative Study. International Journal of Entrepreneurial Behaviour \&Research, 16(5), 389-413. http://dx.doi.org/10.1108/13552551011071878

Merz, G. R., \& Sauber, M. H. (1995). Profiles of Managerial Activities in Small Firms. Strategic Management Journal, 16, 551-564. http://dx.doi.org/10.1002/smj.4250160705

Murphy, G. B., Trailer, J. W., \& Hill, R. C. (1996). Measuring Performance in Entrepreneurship Research. Journal of Business Research, 36, 15-23. http://dx.doi.org/10.1016/0148-2963(95)00159-X

Muske, G. (2002). Family Business: Research from NE 1678 Family Business Research Study. Family Firm Institute Annual Monograph. Bolston, M.A. Family Firm Institute.

Naldi, L., Nordqvist, M., Sjoberg, K., \& Wiklund, J. (2007). Entrepreneurial Orientation, Risk Taking, and Performance in Family Firms. Family Business Review, 20(1), 33-47. http://dx.doi.org/10.1111/j.1741-6248.2007.00082.x

Nooteboom, B. (1993). Research Note: An Analysis of Specificity in Transaction Cost. Organisation Studies, 14, 443-451. http://dx.doi.org/10.1177/017084069301400306

Parker, B. (1990). Strategies for Small Domestic Firms in Decline Industries. International Small Business Journal, 8(1), 23-33. http://dx.doi.org/10.1177/026624268900800102

Patricia, S., \& Kulman, G. A. (2004). Marriage Facts: Balancing Family and Work. Retrieved from http://www.stayhitched.com/balance.htm

Peterson, R., \& Shulman, J. (1987). Capital Structure of Growing Small Firms: A 12-Country Study on Becoming Bankable. International Small Business Journal, 5(4), 10-22. http://dx.doi.org/10.1177/026624268700500401

Pollak, R. A. (1985). A Transaction Cost Approach to Families and Households. Journal of Economic Literature, 23, 581-608. Retrieved from https://www.iei.liu.se/nek/730g83/artiklar/1.253791/pollak.pdf

Poutziouris, P. (1994). The Development of Familia Business. In Burns, P. (Ed), Entrepreneurship and Small Business. New York: Palgrave Macmillan.

Poutziouris, P. (2001). The (Re)-Emergence of Growth Vis-a-Vis Control Dilemma in a Family Business Growth Star: The Case of the UK Taramosalada Kings. In P. Poutziouris \& D. Pistrui (Eds.), Family Business Research in the Third Millennium-Building Bridges between Theory and Practicem (pp. 88-103). Boston, MA: The Family Firm Institute.

Poutziouris, P., \& Chittenden, F. (1996). Family Business or Business Families, Institute for Small Business Affairs and National Westminster Bank Monograph 1.

Poutziouris, P., Smyrnios, K. X., \& Klein, S. B. (2006). Handbook of Research on Family Business. Edward Elgar, Cheltenham. http://dx.doi.org/10.4337/9781847204394

Poza, E. J., Alfred, T., \& Maheshwari, A. (1997). Stakeholder Perceptions of Culture and Management Practices in Family and Family Firms-a Preliminary Report. Family Business Review, 10(2), 135-155. http://dx.doi.org/10.1111/j.1741-6248.1997.00135.x

Rauch, A., Wilklund, J., Freese, M., \& Lumpkin, G. T. (2004). Entrepreneurial Orientation and Business 
Performance: Cumulative Empirical Evidence. Paper Presented at The 23rd Babson College Entrepreneurship Research Conference, Glasgow.

Rogoff, E. G., \& Heck, R. K. Z. (2003). Evolving Research in Entrepreneurship and Family Business: Recognising Family as The Oxygen That Feeds The Fire of Entrepreneurship. Journal of Business Venturing, 18(5), 559-566. http://dx.doi.org/10.1016/S0883-9026(03)00009-0

Romano, C. A., Tanewski, G. A., \& Smyrnios, K. X. (2000). Capital Structure Decision Making: A Model for Family Business. Journal of Business Venturing, 16, 285-310. http://dx.doi.org/10.1016/S0883-9026(99)00053-1

Sathe, V. (2003). Corporate Entrepreneurship: Top Managers and New Business Creation. Cambridge: Cambridge University Press. http://dx.doi.org/10.1017/cbo9780511488719

Schein, E. H. (1983). The Role of the Founders in Creating Organisational Culture. Organisational Dynamics, Summer, 3-28. http://dx.doi.org/10.1016/0090-2616(83)90023-2

Schulze, W. S., Lubatkin, M. H., \& Dino, R. N. (2002). Altruism, Agency and the Competitiveness of Family Firms. Managerial and Decision Economics, 23(4-5), 247-259. http://dx.doi.org/10.1002/mde.1064

Sharma, P. (2004). An Overview of the Field of Family Business Studies: Current Status and Directions for the Future. Family Business Review, 17(1), 1-36. http://dx.doi.org/10.1111/j.1741-6248.2004.00001.x

Sharma, P., Chrisman, J. J., \& Chua, J. H. (1997). Strategic Management of the Family Business: Past Research and Future Challenges. Family Business Review, 10(1), 1-35. http://dx.doi.org/10.1111/j.1741-6248.1997.00001.x

Simon, M., Houghton, S. M., \& Savelli, S. (2003). Out of The Frying Pan. . .? Why Small Business Managers Introduce High-Risk Products. Journal of Business Venturing, 18, 419-440. http://dx.doi.org/10.1016/S0883-9026(02)00083-6

Sirmon, D., \& Hitt, M. (2003). Managing Resources: Linking Unique Resources, Management, and Wealth Creation in Family Firms. Entrepreneurship Theory \& Practice, 27, 339-358. http://dx.doi.org/10.1111/1540-8520.t01-1-00013

Sitkin, S. B., \& Pablo, A. L. (1992). Reconceptualizing the Determinants of Risk Behaviour. Academy of Management Review, 17(1), 9-38. $\quad$ Retrieved from http://www.jstor.org/stable/258646?seq=1\#page_scan_tab_contents

Smallbone, D., Leigh, R., \& North, D. (1995). The Characteristics and Strategies of High Growth Firms. International Journal of Entrepreneurial Behaviour and Research, 1(3), 44-62. http://dx.doi.org/10.1108/13552559510100657

Storey, D. J. (2005). Understanding the Small Business Sector. London: Thomson Learning.

Sung, J., \& Hanna, S. (1996). Factors Related to Risk Tolerance. Financial Counseling and Planning, 7, 11-20. Retrieved from http://www.consumerinterests.org/assets/docs/cia1999/grablejoo.pdf

Teece, D. J. (1982). Towards an Economic Theory of the Multiproduct Firm. Journal of Economic Behaviour and Organisation, 3(1), 39-63. http://dx.doi.org/10.1016/0167-2681(82)90003-8

Uzzi, B. (1996). The Sources and Consequences of Embeddedness For The Economic Performance of Organisations: The Network Effect. American Sociological Review, 61(4), 674-698. http://dx.doi.org/10.2307/2096399

Vanguard, Kuhlman, P. S., \& Kuhlman, G. A. (2004). Marriage Success Training: Balancing Family and Work. Retrieved from http://www.stayhitched.com/balance.htm

Venkatraman, N., \& Ramanujam, V. (1987). Measurement of Business Economic Performance: an Examination of Method Convergence. Journal of Management, 13(1), 109-122. http://dx.doi.org/10.1177/014920638701300109

Wang, Y., Ahmed, P., \& Farquhar, S. (2007). Founders Versus Descendants: Business Performance Comparison in The UK Small and Medium Sized Family Businesses. Journal of Entrepreneurship, 16(2), 173-195. http://dx.doi.org/10.1177/097135570701600203

Ward, J. L. (1987). Keeping the Family Business Healthy: How to Plan for Continuing Growth. Profitability, and Family Leadership. San Francisco, CA: Jossey-Bass.

Ward, J. L. (1997). Growing the Family Business: Special Challenges and Best Practices. Family Business 
Review, 10(4), 323-337. http://dx.doi.org/10.1111/j.1741-6248.1997.00323.x

Wernerfelt, B. (1989). From Critical Resources to Corporate Strategy. Journal of General Management, 14(3), 4-12. Retrieved http://web.mit.edu/bwerner/www/papers/Fromcriticalresourcestocorporatestrategy.PDF

from

Xiao, J. J., Alhabeeb, M. J., Hong, G. S., \& Haynes, G. W. (2001). Attitude toward Risk and Risk-taking Behaviour of Business-Owning Families. The Journal of Consumer Affairs, 35(2), 307-325. http://dx.doi.org/10.1111/j.1745-6606.2001.tb00116.x

Yong, W., \& Panikkos, P. (2010). Entrepreneurial Risk Taking: Empirical Evidence from UK Family Firms. International Journal of Entrepreneurial Behaviour \& Research, 16(5), 370-388. http://dx.doi.org/10.1108/13552551011071841

Zahra, S. A. (1986). A Canonical Analysis of Corporate Entrepreneurship Antecedents and Impact on Performance. Proceedings of the National Academy of Management, 46, 71-75. http://dx.doi.org/10.5465/AMBPP.1986.4978718

Zahra, S. A. (2003). International Expansion of US Manufacturing Family Businesses: The Effect of Ownership $\begin{array}{lllll}\text { and Involvement. Journal of Business Venturing, } & 18(4), \quad 495-512 .\end{array}$ http://dx.doi.org/10.1016/S0883-9026(03)00057-0

Zahra, S. A. (2005). Entrepreneurial Risk Taking in Family Firms. Family Business Review, 18(1), 23-40. http://dx.doi.org/10.1111/j.1741-6248.2005.00028.x

Zahra, S. A., Hayton, J. C., \& Salvato, C. (2004). Entrepreneurship in Family vs Non-family Firms: A Resource Based Analysis of The Effect of Organizational Culture. Entrepreneurship Theory \& Practice, 28(4), 363-381. http://dx.doi.org/10.1111/j.1540-6520.2004.00051.x

Zimmerman, T. S. (2003). Intimate Partnership: Foundation to the Successful Balance of Family and Work. American Journal of Family Therapy, 31, 107-124. http://dx.doi.org/10.1080/01926180301126

\section{Copyrights}

Copyright for this article is retained by the author(s), with first publication rights granted to the journal.

This is an open-access article distributed under the terms and conditions of the Creative Commons Attribution license (http://creativecommons.org/licenses/by/3.0/). 